Article

\title{
Governance Challenges for Implementing Nature-Based Solutions in the Asian Region
}

\author{
Kanako Morita ${ }^{1,2, *}$ and Ken'ichi Matsumoto ${ }^{3,4}$ \\ ${ }^{1}$ Center for Biodiversity and Climate Change, Forestry and Forest Products Research Institute, Japan; \\ E-Mail: kanakomorita@ffpri.affrc.go.jp \\ 2 United Nations University Institute for the Advanced Study of Sustainability (UNU-IAS), Japan \\ ${ }^{3}$ Faculty of Economics, Toyo University, Japan; E-Mail: matsumoto1005@toyo.jp \\ ${ }^{4}$ Research Institute for Global Change, Japan Agency for Marine-Earth Science and Technology, Japan \\ * Corresponding author
}

Submitted: 28 April 2021 | Accepted: 24 June 2021 | Published: 22 October 2021

\begin{abstract}
Nature-based solutions (NbS) are recognized under the United Nations Framework Convention on Climate Change and the Convention on Biological Diversity. This relatively new concept has become a key element in strategies for green recovery from the Covid-19 pandemic. NbS consist of a range of measures that address various societal challenges, including climate change, natural disasters, and water security, by combining human well-being and biodiversity benefits. Although the importance of NbS has been widely recognized, existing studies on aspects of their governance are limited and mainly focus on NbS in European countries. There is little relevant research in other regions, including Asia. This study aimed to explore challenges for NbS governance by analyzing the development and implementation of NbS in Asia. We focused on $\mathrm{NbS}$ in the fields of climate change mitigation and adaptation, disaster risk reduction, and infrastructure. In these three fields, NbS are linked to climate security issues and have been widely implemented in Asian countries. This analysis identified the challenges for NbS governance for countries at different stages of economic development, and for developing measures for NbS with different institutions and actors. It recognizes the importance of a framework that matches the need for NbS with relevant institutions and actors at various scales and in various sectors. Guidelines are required to integrate NbS into strategies and policies at national and local levels and also into international cooperation.
\end{abstract}

\section{Keywords}

Asia; climate change adaptation; climate change mitigation; Convention on Biological Diversity; disaster risk reduction; governance; infrastructure; nature-based solutions; United Nations Framework Convention on Climate Change

\section{Issue}

This article is part of the issue "Climate Change and Security" edited by Yasuko Kameyama (National Institute for Environmental Studies, Japan) and Yukari Takamura (University of Tokyo, Japan).

(C) 2021 by the authors; licensee Cogitatio (Lisbon, Portugal). This article is licensed under a Creative Commons Attribution 4.0 International License (CC BY).

\section{Introduction}

Nature-based solutions (NbS) are a relatively new concept and consist of a range of measures that address various societal challenges, including climate change, natural disasters, food security, human health, water security, and economic and social development, by bringing together human well-being and biodiversity benefits. The increasing importance of $\mathrm{NbS}$ has been recognized under the United Nations Framework Convention on Climate Change (UNFCCC) and the Convention on Biological Diversity (CBD). In addition, $\mathrm{NbS}$ are a key element in strategies for green recovery from the Covid-19 pandemic. In its immediate response framework to Covid-19, the UN states that it will include advice on NbS for development, including for small and medium-sized enterprises (UN, 2020).

The NbS concept was originally developed through the International Union for Conservation of Nature (IUCN) in relation to climate change mitigation and 
adaptation, and biodiversity conservation and management; it was then reconceptualized by the European Commission (EC) to explain social and economic goals more explicitly (Dorst et al., 2019; Nesshöver et al., 2017). The IUCN defines NbS as "actions to protect, sustainably manage, and restore natural or modified ecosystems, that address societal challenges effectively and adaptively, simultaneously providing human well-being and biodiversity benefits" (Cohen-Shacham et al., 2016). The EC defines NbS as "solutions that are inspired and supported by nature, which are cost-effective, simultaneously provide environmental, social and economic benefits and help build resilience" (European Commission [EC], 2021a). The IUCN's definition is more focused on nature, whereas the EC's definition is focused on humans, and related to the economy and markets (Mendes et al., 2020).

$\mathrm{NbS}$ include ecosystem restoration approaches, issue-specific ecosystem-related approaches (e.g., ecosystem-based mitigation and adaptation, and ecosystem-based disaster risk reduction [Eco-DRR]), infrastructure-related approaches (e.g., green infrastructure), ecosystem-based management approaches, and ecosystem protection approaches (Cohen-Shacham et al., 2016). Although NbS are a relatively new concept, the approaches used for $\mathrm{NbS}$, including those relating to climate change mitigation and adaptation and forest management, are not considered new (Morello et al., 2018; Springgay, 2019).

Although the importance of $\mathrm{NbS}$ has been widely recognized around the world, there have been limited studies on the governance aspects of NbS (Albert et al., 2019; Nelson et al., 2020; Nesshöver et al., 2017). The majority of existing studies focus on possible plans for NbS in European countries (Faivre et al., 2017; Frantzeskaki, 2019; Nesshöver et al., 2017), especially in the urban context. Existing studies also focus on the contribution of $\mathrm{NbS}$ to achieving more sustainable and resilient urban areas or cities, and the conditions or frameworks that guide the implementation of $\mathrm{NbS}$ (Dorst et al., 2019; Frantzeskaki et al., 2019; Raymond et al., 2017). The European Union (EU) is an important promotor of $\mathrm{NbS}$, adopting the concept in its early stages and providing financial support for both NbS-related academic research and implementation in cities (Mendes et al., 2020). The EU has considered NbS broadly in terms of cross-sectoral governance including financing at a regional level (which is between national and global levels) by linking NbS with the European Green Deal and green recovery from the Covid-19 pandemic (Science for Environment Policy, 2021). In Europe, there are links also between various actors and $\mathrm{NbS}$, through the publication of the European Investment Bank's guide to financing NbS projects and the "EU Business @ Biodiversity Platform," which provides a forum for dialogue and policy development on the connections between business and biodiversity at the EU level (EC, 2021b; European Investment Bank, 2018). Other regions, including Asia, lack studies on the governance aspects of $\mathrm{NbS}$ (Lechner et al., 2020). In Asia, there is no regional strategy on $\mathrm{NbS}$, and there is limited discussion on the relationships between NbS and cross-sectoral national and local governance which could promote NbS more widely. There is also limited connectivity between $\mathrm{NbS}$ and green recovery strategies in Asia. Because there are many developing countries in Asia, not only national and local governance, but also governance of international cooperation is crucial for NbS.

This study aimed to explore challenges for NbS governance by analyzing the development and implementation of $\mathrm{NbS}$ in the East, Southeast, and South Asian regions. In this analysis, governance included national and local governance as well as governance related to international cooperation for Asian countries. We focused on NbS in the fields of climate change mitigation and adaptation, disaster risk reduction (DRR), and infrastructure because these are the fields that were not originally referred to as NbS but have been widely implemented in Asian countries. NbS in these three fields are linked to climate security issues. Although climate security does not have an agreed definition, in this article climate security refers to threats caused by climate change to national, human, international, and ecological security (McDonald, 2013). Measures to increase climate security include those for climate change mitigation and adaptation, and for building resilience (Kameyama \& Ono, 2021). Compared with discourse on national, human, and international security, the ecological security discourse has had limited impact on policy or academic debates (McDonald, 2013). NbS in the three fields shown above could provide approaches for a wide range of discourses on climate security, including ecological security.

\section{Exploring Governance Challenges for Nature-Based Solutions}

\subsection{Governance for Nature-Based Solutions}

The literature on governance for $\mathrm{NbS}$ remains limited, as noted above. Most NbS studies highlight the novelty of the NbS concept and its establishment in the European urban context (Hanson et al., 2020). Although current governance-related discussions on $\mathrm{NbS}$ mainly focus on urban sustainability, $\mathrm{NbS}$ involve multiple actions that are implemented over a broad range of landscapes and seascapes, and across jurisdictional boundaries (Seddon, Chausson, et al., 2020). NbS governance requires active cooperation and coordinated action between multiple actors whose priorities, interests, or values may not be coordinated, and may even conflict (Dale et al., 2019; Seddon, Chausson, et al., 2020). The NbS literature generally promotes a comprehensive governance approach that coordinates the different policies, regulations, and finance related to the different functions of $\mathrm{NbS}$ (Dorst et al., 2019; Frantzeskaki, 2019; Xing et al., 2017). 
Studies concerning the implementation of $\mathrm{NbS}$ in Asia are particularly limited. Hanson et al. (2020) conducted a qualitative review of 112 scientific peerreviewed publications that use the term $\mathrm{NbS}$ and found that only around $14 \%$ of publications concerned Asian contexts. A study by Lechner et al. (2020) is one of the few that discusses the application of NbS in Southeast and East Asia, where urban blue (i.e., water) and green (i.e., vegetation) spaces are increasingly being degraded and lost because of rapid urbanization. They assessed the socio-ecological challenges to the application of $\mathrm{NbS}$ in Southeast and East Asia and showed that South-South and North-South collaboration should be a priority for government, planners, and academics.

\subsection{Analytical Framework and Scope}

We identified the governance challenges for NbS that need to be addressed in Asia by analyzing how the existing types of $\mathrm{NbS}$ have been developed and implemented in the region, and by identifying the governance challenges for $\mathrm{NbS}$ that tend to vary between the developed and developing countries in Asia. As noted earlier, we focused on $\mathrm{NbS}$ in the fields of climate change mitigation and adaptation, DRR, and infrastructure. Although the concept of $\mathrm{NbS}$ is relatively new and the term $\mathrm{NbS}$ is not yet widely used in Asia, the components of NbS, such as ecosystem-based mitigation and adaptation, Eco-DRR, and green infrastructure are already being implemented. In our analysis, we use the term "green infrastructure" as a concept that includes both green and blue infrastructure and spaces because the term is often used as a broad concept in Asian countries.

Much of the literature on NbS (including the literature that does not explicitly use the term NbS) in the region is written in the relevant native language. In our analysis we only used studies and data written in English to ensure consistency among countries. Owing to the limited information and data on NbS published in English, this article did not attempt to provide comprehensive coverage of all NbS measures in all sectors over time. We used both academic and nonacademic studies and data. The cases that we used in this article included both developed and developing countries in the East, Southeast, and South Asian regions.

\section{Nature-Based Solutions in the Three Areas}

\subsection{Nature-Based Solutions for Climate Change Mitigation and Adaptation}

This section identifies how NbS for mitigation and adaptation have been implemented in Asian countries. We show that NbS for mitigation are quite well established in national strategies and policies, as well as in the international financial mechanisms and among donors. In contrast, recognition of and funding for NbS for adaptation are more sporadic and less well established in the national strategies and policies and financial mechanisms. As mentioned above, although the links between $\mathrm{NbS}$ and strategies for green recovery from the Covid-19 pandemic are being discussed in the EU, their links with cross-sectoral strategies are not discussed much in Asian countries.

\subsubsection{Definition and Background of Nature-Based} Solutions for Mitigation and Adaptation

$\mathrm{NbS}$ have the potential to enhance climate change mitigation and climate resilience. As described above, the NbS concept was originally developed in relation to climate change mitigation and adaptation as well as biodiversity conservation and management, and there is a wide range of literature on these topics (Chausson et al., 2020; Griscom et al., 2017, 2020; Seddon, Daniels, et al., 2020). $\mathrm{NbS}$ for mitigation are also referred to as natural climate solutions (NCS; Griscom et al., 2020). NCS are a set of protection, restoration, and improved land management pathways that produce climate change mitigation outcomes (Griscom et al., 2020). They can reduce and reverse emissions from agriculture, forestry, and other land use (AFOLU) sectors, and are capable of covering around one third of the mitigation required by 2030 to achieve the goals of the Paris Agreement of the UNFCCC (Griscom et al., 2017, 2020).

$\mathrm{NbS}$ for adaptation are widely referred to using the term ecosystem-based adaptation (EbA), which uses "biodiversity and ecosystem services as part of an overall adaptation strategy to help people to adapt to the adverse effects of climate change" (Secretariat of the Convention on Biological Diversity, 2009). Thus, EbA measures form a part of NbS (Cohen-Shacham et al., 2016). Over the last two decades, there has been a significant increase in the implementation of NbS for adaptation (UN Environment Programme [UNEP], 2021).

At the international level, the contribution of $\mathrm{NbS}$ to mitigation and adaptation was emphasized when all parties to the Paris Agreement were called on to recognize "the importance of the conservation and enhancement, as appropriate, of sinks and reservoirs of the greenhouse gases," and to note "the importance of ensuring the integrity of all ecosystems, including oceans, and the protection of biodiversity" (UN, 2015). The Agreement also refers to ecosystems, forests, and natural resources in its articles, including the article regarding "reducing emissions from deforestation and forest degradation, and the role of conservation, sustainable management of forests and enhancement of forest carbon stocks in developing countries (REDD+)" (Seddon, Daniels, et al., 2020; Seddon et al., 2019).

REDD+, which can be an NbS or NCS, is a framework that aims to contribute to climate change mitigation and may produce co-benefits such as climate change adaptation and biodiversity conservation (Morita \& Matsumoto, 2018). The AFOLU sectors' contribution to mitigation, including through REDD+, has been an 
important part of the agenda within the UNFCCC. REDD+ has received international attention from various actors because it may substantially contribute to mitigation and provide benefits to both developed and developing countries. Developed countries could reduce emissions at a relatively low cost by supporting REDD+ (Stern, 2007), while REDD+ provides financial incentives for developing countries to reduce emissions in the forest sector. Compared with other NbS, the REDD+ framework and approaches are considered to be more developed in terms of fitting clearly into international conventions and having established rules (e.g., national forest monitoring systems, safeguards, and results-based finance under the Warsaw Framework for REDD+), as well as clear links to international cooperation mechanisms (including public and private finance sources). Asian countries that are implementing REDD+ have links with various donors, such as Norway's Climate and Forest Partnership with Indonesia, the Green Climate Fund (GCF) REDD+ support to Indonesia, and Japan's REDD+ support to Indonesia, Vietnam, Cambodia, and Lao PDR. However, REDD+ still has various governance challenges to overcome. Its current governance suffers from fragmentation, which requires coordination among institutions and actors from international to local levels, and there are issues relating to the effectiveness and performance of REDD+ that need to be addressed (Arts et al., 2019; Dong-hwan Kim et al., 2020; Korhonen-Kurki et al., 2019). The governance challenges include coordination between donors/financial sources and recipients.

EbA was touched on in the discussion on adaptation within the UNFCCC (Morita \& Matsumoto, 2015). The UNFCCC created an EbA database on its website (currently included in the Adaptation Knowledge Portal of the UNFCCC website), and a technical workshop on EbA was held in 2013. Some topics of discussion under the UNFCCC, including REDD+ safeguards and EbA, were also discussed under the CBD (Morita \& Matsumoto, 2015, 2018).

The UN Environment Programme (UNEP) is among the organizations that have promoted NbS for mitigation and adaptation internationally, through the UN-REDD Programme (working with the Food and Agriculture Organization of the UN [FAO] and the UN Development Programme [UNDP]) which supports Asian countries such as Vietnam, and through EbA projects in Asian countries such as Cambodia (UNEP, 2020). At the national level, $\mathrm{NbS}$ are recognized in nationally determined contributions (NDCs), which are the efforts by each country to reduce national emissions and adapt to climate change impacts under the UNFCCC (United Nations Framework Convention on Climate Change [UNFCCC], 2021b). Seddon et al. (2019) show that the majority of NDCs include NbS; at least $66 \%$ of the Paris Agreement signatories include NbS actions or targets as a part of their mitigation and/or adaptation components, although more concrete and evidence-based targets for NbS are required. Laurans et al. (2016) analyzed
$\mathrm{NbS}$ in the intended nationally determined contributions (INDCS) and found that NbS were clearly visible in $28 \%$ of INDCs. NbS are commonly used in Africa and South America/the Caribbean, but much less so in Asia (excluding China) and in Europe (Laurans et al., 2016). China and Mexico highlight NbS in their INDCs. Among developed countries, Japan and New Zealand have the most detailed INDCs, which include detailed measures regarding mitigation through land use, whereas the EU mainly spells out the results that need to be achieved (Laurans et al., 2016).

\subsubsection{Nature-Based Solutions for Mitigation in Asian Countries}

In regard to NbS for mitigation, as described above, Japan submitted a detailed INDC in 2015 describing NbS (Laurans et al., 2016). Japan's INDC set a target of a $26 \%$ reduction in greenhouse gas emissions by fiscal year (FY) 2030 compared with FY 2013 levels, including a target for removals by the land use, land use change, and forestry sector (approximately 37 million t- $\mathrm{CO}_{2}$; UNFCCC, 2021a). South Korea, in its updated NDC submitted in 2020, provided a target of a $24 \%$ reduction in greenhouse gas emissions below 2017 levels, but did not identify the target of removals (UNFCCC, 2021a).

The most prominent support provided by donors in developed countries to Asian developing countries for $\mathrm{NbS}$ is through REDD+. Japan was the second largest donor of the total REDD+ funds committed between 2006 and 2015 (the total funding committed by all donors was 16.7 billion USD; Do-hun Kim et al., 2019).

Among all the REDD+ recipient countries, Indonesia, India, and China received the second, third, and fifth largest amounts of funding, respectively, from the total REDD+ funds between 2006 and 2015 (total funds received by all recipients [excluding funds received by donors from other donors] were 9.69 billion USD; Do-hun Kim et al., 2019). Nepal, Vietnam, Lao PDR, and the Philippines were also major recipient countries in Asia (Do-hun Kim et al., 2019).

\subsubsection{Nature-Based Solutions for Adaptation in Asian Countries}

In terms of $\mathrm{NbS}$ for adaptation, at the international level, the Asian countries in the G20-Japan, South Korea, China, India, and Indonesia-have already indicated the importance of implementing EbA as well as DRR (see Section 3.2; Prabhakar et al., 2019). The G20 Osaka Leader's Declaration, adopted under Japan's presidency in 2019, includes references to ecosystem-based approaches and $\mathrm{NbS}$, and there were increased references to EbA and DRR at the G20 Summit in Japan (Ministry of the Environment, 2020; Warren, 2020). There has been recognition of the importance of integrating ecosystem-based approaches into national adaptation plans by both Japan and South Korea (Prabhakar 
et al., 2019). In particular, Japan's national strategies, including the national adaptation plan, specify ecosystem-based approaches (Prabhakar et al., 2019).

China is one of the few Asian developing countries that highlights NbS in its INDC (Laurans et al., 2016). The Chinese NDC states that "climate change has significant impacts on global natural ecosystems" (UNFCCC, 2021a). Other developing countries that emphasized NbS for adaptation in their NDCs include Mongolia, Vietnam, and Nepal (Seddon et al., 2019). More recently, a number of countries including Thailand, Brunei Darussalam, Cambodia, and the Maldives, highlighted $\mathrm{NbS}$ for adaptation when they updated their NDCs in 2020 (UNFCCC, 2021a).

The amount of public international funding provided to $\mathrm{NbS}$ for adaptation is only 3.8-8.7 billion USD, or around $0.6 \%-1.4 \%$ of total climate finance flows in 2018 (Swann et al., 2021). Overall funding for NbS for adaptation in 2018 was supported by a small number of major bilateral donors, including Germany, the United Kingdom, Japan, and Sweden, and major multilateral donors, including the EU, the Asian Development Bank (ADB), the GCF, and the International Fund for Agricultural Development (Swann et al., 2021). Around a half of the total public funding for $\mathrm{NbS}$ for adaptation was allocated to countries in Sub-Saharan Africa and South and Central Asia (Swann et al., 2021).

Compared with REDD+, NbS for adaptation, such as $\mathrm{EbA}$, have not yet been clearly identified in the international finance and donor-funded programs and projects. As mentioned above, the amount of public international funding provided to $\mathrm{NbS}$ for adaptation is comparatively small (Swann et al., 2021). Major international finance mechanisms/multilateral donors that have supported NbS for adaptation implementation in Asian countries are the Global Environment Facility (GEF), Adaptation Fund, GCF, and the ADB. In 2020, the GEF, Adaptation Fund, and GCF submitted inputs on finance for $\mathrm{NbS}$ to the Forum of the Standing Committee on Finance, which provides a platform for a wide range of actors to discuss climate finance topics (UNFCCC, 2020).

The GEF provides funding to support developing countries to achieve the objectives of international environmental conventions and serves as the financial mechanism for five conventions, including the UNFCCC and the CBD (Global Environment Facility [GEF], 2021b). It has supported a number of programs and projects such as building climate resilience of urban systems through EbA (Bhutan, Cambodia, Lao PDR, and Myanmar) and EbA for climate-resilient development (Nepal). The GEF's NbS-related programs/projects have been implemented by agencies including the UNEP and UNDP, and projects have been executed mainly by the governments of recipient countries. Because the GEF currently aims to prioritize integrated programs and projects that address more than one global environmental problem (GEF, 2021a), $\mathrm{NbS}$, which can produce multiple benefits, are likely to align with the GEF strategy.
The Adaptation Fund under the Kyoto Protocol of the UNFCCC has supported programs/projects such as enhancing climate resilience in the Mekong subregion through EbA (Thailand and Vietnam). As with GEF funding, the programs/projects have been implemented by agencies including the UNEP and UNDP and executed mainly by recipient governments. The GCF, established under the UNFCCC, has supported programs/projects on $\mathrm{NbS}$ for adaptation, including building a resilient Churia region (Nepal). The ADB has supported more infrastructure-related programs/projects such as building climate change resilience in Asian coastal cities (South and Southeast Asia).

\subsection{Ecosystem-Based Disaster Risk Reduction}

Compared with NbS for mitigation and adaptation, the amount and status of international finance flows to Eco-DRR is not clear. Existing programs/projects funded by international finance mechanisms/multilateral donors do not explicitly highlight Eco-DRR, and there is a lack of clarity over whether EbA-related programs/ projects include Eco-DRR elements.

\subsubsection{Definition and Background of Ecosystem-Based Disaster Risk Reduction}

Eco-DRR is "the sustainable management, conservation and restoration of ecosystems to reduce disaster risk, with the aim of achieving sustainable and resilient development" (Estrella \& Saalismaa, 2013, p. 30). Eco-DRR is often discussed with EbA, as both are important elements of overall climate change adaptation and DRR strategies (Secretariat of the Convention on Biological Diversity, 2019). The Secretariat of the CBD has developed overarching considerations for EbA and Eco-DRR design and implementation, and a stepwise approach for their effective design and implementation (Secretariat of the Convention on Biological Diversity, 2019).

At the international level, the Sendai Framework for Disaster Risk Reduction 2015-2030, which was adopted at the Third UN World Conference on DRR in 2015 (hosted by Japan and with the UN Office for Disaster Risk Reduction [UNDRR, previously UNISDR] serving as coordinating body), calls for the implementation of ecosystem-based approaches for shared resources (e.g., within river basins and along coastlines) to build resilience and reduce disaster risk through transboundary cooperation. The UNDRR is key for the promotion of Eco-DRR. For example, it provides suggestions on ways to exploit the growing evidence base to enhance the integration of Eco-DRR and other $\mathrm{NbS}$ (such as EbA) into DRR strategies and national development plans using good practices from Asia and other regions (UN Office for Disaster Risk Reduction [UNDRR], 2020). In addition, it has published a guide providing practical information on establishing and implementing $\mathrm{NbS}$, especially in relation to DRR and climate change adaptation, and on helping 
to implement the Sendai Framework (UNDRR, 2021). Although linkages between Eco-DRR and other measures, as well as among strategies and plans, are broadly discussed in the existing literature, there are limited studies on Eco-DRR from a governance perspective (Triyanti \& Chu, 2018; Wickramasinghe, 2021). The lack of discussion on Eco-DRR from a governance perspective is considered to be partly because Eco-DRR studies are still dominated by the natural sciences (Triyanti \& Chu, 2018). The challenges related to governance for Eco-DRR include limited visibility to policy makers as a potential solution, the invisibility of benefits from Eco-DRR measures, and inadequate financial incentives to invest in Eco-DRR (Wickramasinghe, 2021).

\subsubsection{Ecosystem-Based Disaster Risk Reduction in Asian Countries}

Among the developed countries in Asia, Japan is considered to be a key promoter of Eco-DRR, with its government proactively advocating for it (Japan International Cooperation Agency, 2021; Wickramasinghe, 2021). In 2016, the Ministry of the Environment in Japan published a handbook for practitioners on Eco-DRR, which introduced some Eco-DRR approaches and key points for their adoption (Ministry of the Environment, 2016). In addition, Eco-DRR is clearly integrated into national plans in Japan. For example, the Fundamental Plan for National Resilience in 2018 refers to the importance of implementing and promoting the concepts of Eco-DRR and green infrastructure to enhance resilience (Cabinet Secretariat, 2018). Japan has experience in integrating ecosystem perspectives into water related DRR (e.g., river and coastal DRR), and the existing literature identifies good practices and case studies for Eco-DRR in Japan (Furuta \& Shimatani, 2018; Kato \& Huang, 2021; Mabon, 2019), although discussion on integrating those case studies to national and local governance is limited. The literature on Eco-DRR in Asia is largely centered on Japan. In South Korea, although there are studies on ecosystems and DRR, such as the links between forest management and DRR, few existing studies directly discuss Eco-DRR (Lee et al., 2018). As for donors, the Japan International Cooperation Agency has broadly supported Eco-DRR in developing countries, including in Myanmar and China (Japan International Cooperation Agency, 2021), and integration of Eco-DRR and Japanese bilateral cooperation is observed. However, Eco-DRR is not clearly earmarked in multilateral and bilateral cooperation for developing countries in Asia.

There are few studies that comprehensively examine Eco-DRR implementation in developing countries (UNDRR, 2020). The UNDRR (2020) examined various case studies in the Asia-Pacific, including Eco-DRR measures in river/flood plains (India), ecologically friendly alternatives to traditional flood defenses and drainage systems in cities (China), and participatory approaches to hydraulic engineering challenges that use and create ecosystem services to benefit society (Indonesia). The case studies show that there are good examples of integrating NbS into DRR strategies. For example, the National Disaster Management Plan of India in 2019 included the implementation of ecosystem-based approaches for river basins, mountainous regions, and coastlines (UNDRR, 2020). The Myanmar National Framework for Community Disaster Resilience in 2017 adopted an inclusive planning process to identify and implement measures that are structural, ecosystem-based and nonstructural at the household level and community level, to reduce disaster risk, and the Myanmar Action Plan on Disaster Risk Reduction in 2017 set out techniques for integrating disaster and climate risk into village development planning and implementation to apply Eco-DRR measures as one of the priorities (UNDRR, 2020). These examples indicate that in some developing countries in Asia, the Eco-DRR is integrated to national strategies on DRR. However, because Eco-DRR is not fully integrated into international cooperation, one challenge for developing countries is the lack of a link between Eco-DRR implementation and financial and technical support.

\subsection{Green Infrastructure}

Because the definition of green infrastructure in Asia is incomplete, identifying the governance challenges of green infrastructure under $\mathrm{NbS}$ is difficult compared with the other NbS areas analyzed above. Furthermore, compared with $\mathrm{NbS}$ for mitigation and adaptation and Eco-DRR, green infrastructure lacks formal links with international frameworks, such as the UNFCCC, CBD, and UNDRR-related frameworks. The understanding and implementation of green infrastructure also varies among countries.

\subsubsection{Definition and Background of Green Infrastructure}

Although green infrastructure is categorized under NbS, it does not have a widely accepted definition. Benedict and McMahon (2002, p. 12) defined green infrastructure as an "interconnected network of green space that conserves natural ecosystem values and functions and provides associated benefits to human populations," and the EU uses a similar definition (EC, 2019; Escobedo et al., 2019). However, in Asia, there is no common definition for green infrastructure. For example, the Japanese government recognizes that green infrastructure aims to use the natural environment's diverse functions and obtains diverse effects, such as improving the local aesthetics and living environment and preventing or reducing disasters (Ministry of Land, Infrastructure, Transport and Tourism, 2019). In China, green infrastructure in cities is placed under the umbrella of urban greening (Escobedo et al., 2019). Furthermore, the term "green infrastructure" is used differently in the context of green finance and investment, which uses a pragmatic definition of 
green infrastructure that places sectors and technologies that qualify as "green" under sustainable finance taxonomies, including renewable energy, sustainable transport, and sustainable waste management (OECD, 2020).

\subsubsection{Green Infrastructure in Asian Countries}

The Japanese government emphasizes the role of green infrastructure and Eco-DRR, and promotes green infrastructure like Eco-DRR (Ministry of the Environment, 2016). In Japan, the concept of green infrastructure has been highlighted especially within the literature of infrastructure and disaster management (Ministry of Land, Infrastructure, Transport and Tourism, 2019), while the concept of Eco-DRR has been mainly promoted within the literature relating to ecosystem services (Ministry of the Environment, 2016; Wickramasinghe, 2021). Furthermore, in 2020, the Green Infrastructure Public-Private Partnership Platform was started, led by the Ministry of Land, Infrastructure, Transport and Tourism of Japan. This links actors such as national government, local governments, the private sector, and academia to contribute to designing and implementing comprehensive green infrastructure solutions (Dewit, 2020). In South Korea, there are also some case studies such as green infrastructure within NbS practices in the Cheonggyecheon River in Seoul (Asian Development Bank [ADB], 2016), hubs and links of green infrastructure in the Seoul metropolis (Kang \& Kim, 2015), and green infrastructure network planning for a coastal urban area in Busan (Jeong et al., 2021). The importance of green infrastructure has been recognized in both countries, and a platform such as the Japanese Green Infrastructure Public-Private Partnership Platform has the potential to link relevant institutions and actors. However, similar to Eco-DRR, the integration of local actions with national and local governance faces challenges. Furthermore, green infrastructure under $\mathrm{NbS}$ is not clearly identified in the multilateral and bilateral cooperation for developing countries in Asia. This may be partially because of the different definitions of green infrastructure.

Among developing countries in Asia, China has an active academic dialogue regarding green infrastructure (Hu et al., 2020). China has not issued any national green infrastructure guidance policy; however, ecoenvironmental guidelines recently announced in the country reflect the functional necessity of green infrastructure, ecosystem services, and biodiversity conservation (Hu et al., 2020). The ideology of "ecological civilization" is catalyzing the promotion of green infrastructure plans and thinking in China (Hu et al., 2020). In India, green infrastructure is not clearly integrated into the national strategies and policies, although the Centre for Science and Environment, supported by the Ministry of Housing and Urban Affairs of India, published Green Infrastructure: A Practitioner's Guide in 2017, which introduced methods and strategies for water sensitive urban design and planning (Rohilla et al., 2017). In addi- tion, green infrastructure initiatives are seen in city level, such as Blue-Green Masterplans in Delhi and Bhopal (Udas-Mankikar \& Driver, 2021). Although the green infrastructure concept is not widely used in developing countries in Asia, the ADB (2016) has developed principles for applying green infrastructure to build resilience in Mekong towns, including that green infrastructure needs to be a strategically planned and interconnected network that is included in town master plans, and that it needs to involve all relevant local actors. It has also developed 10 strategies for green infrastructure and $\mathrm{NbS}$ for Mekong town development, such as greening of core urban areas, and greening of towns on rivers and coasts. Furthermore, the ADB provides case studies of green infrastructure implementation, such as landslide slope stabilization (Nepal), river cleanup and restoration (Philippines), and wetland construction (Malaysia; ADB, 2016). The GEF has published a study on good practice for green infrastructure such as NbS for erosion control in a GEF-supported climate resilient rural infrastructure project (Vietnam), which was implemented by the ADB and UNDP (GEF, 2020). In developing countries in Asia, green infrastructure is not yet clearly linked to national governance or international cooperation, including finance.

\section{Discussion and Conclusions}

In this article, we analyzed the development and implementation of the three existing types of NbS-NbS for climate change mitigation and adaptation, Eco-DRR, and green infrastructure-in Asia. We also attempted to understand common and specific governance challenges for NbS in Asian countries.

It is difficult to analyze the development and implementation of NbS in Asia comprehensively, in both periodical and sectorial terms, because of the limited literature and data published in English. However, we found that, although the current literature on NbS is mainly focused on the European context, many Asian countries have developed and implemented $\mathrm{NbS}$ in their own national contexts, and several countries have already included NbS in their national strategies or plans. Because many of the Asian countries are developing countries, NbS governance discussion in Asia includes governance related to international cooperation.

We found that there is a need to coordinate fragmented institutions and actors to move forward with the implementation of NbS in Asia. In addition, there is a need to use the experience and lessons learned from the past, including from programs/projects and measures that are not necessarily referred to as NbS. The fragmentation of institutions and actors is evident in the different types of $\mathrm{NbS}$ and each type has unique challenges. REDD+ and EbA are linked to the UNFCCC and the $C B D$, while Eco-DRR is linked to the UNDRR-related framework. Green infrastructure lacks a formal link with any international framework. This fragmentation makes 
it difficult to compare different types of NbS in each country. Particularly for developing countries, the different types of $\mathrm{NbS}$ are supported by various actors (including international finance mechanisms and donors), making it more difficult for these countries to coordinate $\mathrm{NbS}$ implementation and to integrate NbS into their national strategies and plans. Furthermore, compared with Europe, in Asia, the links between NbS and strategies for a green recovery from the Covid-19 pandemic are limited. There is also a limited framework to link the various actors (including private sector and financial institutions) and $\mathrm{NbS}$ in both developed and developing countries.

This article mainly focused on the three areas of NbS noted above, which already include both practical and academic discussion, and could provide approaches for a wide range of discourses on climate security (i.e., national, human, international, and ecological security). It is notable that NbS approaches, which directly contribute to the resilience of ecosystems, could contribute to the ecological security discourses under climate security that currently have less impact on policy or academic debates. It should be noted that NbS also include solutions addressing other societal issues, such as food security and human health, which have limited discussion compared with the three areas discussed in this article. In 2021, the FAO and The Nature Conservancy published three reports on NbS in agriculture (The Nature Conservancy, 2021). The FAO considers agricultural $\mathrm{NbS}$ as an effective, long-term, cost efficient approach to address sustainable land and water resources management and climate change (Food and Agriculture Organization of the UN, 2021). In addition, in 2021, the World Health Organization and IUCN established a new "Expert Working Group on Biodiversity, Climate, One Health and Nature-based Solutions," which aims to develop guidance and tools to support the implementation of One Health approaches (combining human, animal, and environmental health) and $\mathrm{NbS}$ (World Health Organization, 2021). Such NbS approaches will be also important in Asia and require both practical and academic dialogue. Because it is likely that NbS will encompass a wide range of issues and measures, it is essential to link the needs for NbS with relevant institutions and actors not only within countries but also across countries including in the relationships between developed and developing countries. As one solution to overcome the governance challenges, we suggest building a national and regional framework that matches the need for NbS with relevant institutions and actors at various scales and sectors and creates guidelines to integrate $\mathrm{NbS}$ into strategies and policies at national and local levels and also into international cooperation that promotes measures for $\mathrm{NbS}$.

\section{Acknowledgments}

This research is supported by JSPS KAKENHI grant numbers 19K12467, 18H03428, 18K11800, 19H04340, the
Environment Research and Technology Development Fund (JPMEERF20181001) of the Environmental Restoration and Conservation Agency of Japan, Research Institute for Humanity and Nature: Feasibility Project 14200158, the Diversity Promotion Office Fund of Forestry and Forest Products Research Institute, and the Integrated Research Program for Advancing Climate Models (TOUGOU program) grant number JPMXD0717935715 of the Ministry of Education, Culture, Sports, Science and Technology of Japan. We thank Amanda Fitzgibbons, PhD, and Leonie Seabrook, PhD, from Edanz (https://jp.edanz.com/ac) for editing a draft of this manuscript.

\section{Conflict of Interests}

The authors declare no conflict of interests.

\section{References}

Albert, C., Schröter, B., Haase, D., Brillinger, M., Henze, J., Herrmann, S., Gottwald, S., Guerrero, P., Nicolas, C., \& Matzdorf, B. (2019). Addressing societal challenges through nature-based solutions: How can landscape planning and governance research contribute? Landscape and Urban Planning, 182, 12-21. https://doi. org/10.1016/j.landurbplan.2018.10.003

Arts, B., Ingram, V., \& Brockhaus, M. (2019). The performance of REDD+: From global governance to local practices. Forests, 10(10), Article 837. https://doi. org/10.3390/f10100837

Asian Development Bank. (2016). Nature-based solutions for building resilience in towns and cities: Case studies from the Greater Mekong Subregion. https://www.adb.org/publications/nature-basedsolutions-building-resilience-towns-cities-gms

Benedict, M. A., \& McMahon, E. T. (2002). Green infrastructure: Smart conservation for the 21st century. Renewable Resources Journal, 20(3), 12-17.

Cabinet Secretariat. (2018). Fundamental plan for national resilience-For building a strong and flexible country. https://www.cas.go.jp/jp/seisaku/ kokudo_kyoujinka/en/fundamental_plan.pdf

Chausson, A., Turner, B., Seddon, D., Chabaneix, N., Girardin, C. A. J., Kapos, V., Key, I., Roe, D., Smith, A., Woroniecki, S., \& Seddon, N. (2020). Mapping the effectiveness of nature-based solutions for climate change adaptation. Global Change Biology, 26(11), 6134-6155. https://doi.org/10.1111/gcb.15310

Cohen-Shacham, E., Walters, G., Janzen, C., \& Maginnis, S. (2016). Nature-based solutions to address global societal challenges. International Union for Conservation of Nature. https://doi.org/10.2305/IUCN.CH. 2016.13.en

Dale, P., Sporne, I., Knight, J., Sheaves, M., EslamiAndergoli, L., \& Dwyer, P. (2019). A conceptual model to improve links between science, policy and practice in coastal management. Marine Policy, 103, 42-49. 
https://doi.org/10.1016/j.marpol.2019.02.029

Dewit, A. (2020). Japan's integration of all-hazard resilience and Covid-19 countermeasures. The AsiaPacific Journal, 18(11), Article 5402. https://apjjf. org/2020/11/DeWit.html

Dorst, H., van der Jagt, A., Raven, R., \& Runhaar, H. (2019). Urban greening through nature-based solutionsKey characteristics of an emerging concept. Sustainable Cities and Society, 49, Article 101620. https:// doi.org/10.1016/j.scs.2019.101620

Escobedo, F. J., Giannico, V., Jim, C. Y., Sanesi, G., \& Lafortezza, R. (2019). Urban forests, ecosystem services, green infrastructure and nature-based solutions: Nexus or evolving metaphors? Urban Forestry and Urban Greening, 37, 3-12. https://doi.org/ 10.1016/j.ufug.2018.02.011

Estrella, M., \& Saalismaa, N. (2013). Ecosystem-based disaster risk reduction (Eco-DRR): An overview. In F. G. Renaud, K. Sudmeier-Rieux, \& M. Estrella (Eds.), The role of ecosystems in disaster risk reduction (pp. 26-54). United Nations University Press.

European Commission. (2019). Guidance on a strategic framework for further supporting the deployment of EU-level green and blue infrastructure (Commission staff working document). https://ec.europa. eu/environment/nature/ecosystems/pdf/SWD_ 2019_193_F1_STAFF_WORKING_PAPER_EN_V4 P1_1024680.PDF

European Commission. (2021a). Nature-based solutions. https://ec.europa.eu/info/research-and-innovation/ research-area/environment/nature-basedsolutions_en

European Commission. (2021b). The EU Business @ Biodiversity Platform. https://ec.europa.eu/ environment/biodiversity/business/index_en.htm

European Investment Bank. (2018). Investing in nature: Financing conservation and nature-based solutions. https://www.eib.org/attachments/pj/ncff-investnature-report-en.pdf

Faivre, N., Fritz, M., Freitas, T., de Boissezon, B., \& Vandewoestijne, S. (2017). Nature-based solutions in the EU: Innovating with nature to address social, economic and environmental challenges. Environmental Research, 159, 509-518. https://doi.org/10.1016/ j.envres.2017.08.032

Food and Agriculture Organization of the UN. (2021). Agriculture nature-based solutions. http://www. fao.org/land-water/overview/integrated-landscapemanagement/nature-based-solutions/en

Frantzeskaki, N. (2019). Seven lessons for planning nature-based solutions in cities. Environmental Science and Policy, 93, 101-111. https://doi.org/ 10.1016/j.envsci.2018.12.033

Frantzeskaki, N., McPhearson, T., Collier, M. J., Kendal, D., Bulkeley, H., Dumitru, A., Walsh, C., Noble, K., van Wyk, E., Ordóñez, C., Oke, C., \& Pintér, L. (2019). Nature-based solutions for urban climate change adaptation: Linking science, policy, and practice com- munities for evidence-based decision-making. BioScience, 69(6), 455-466. https://doi.org/10.1093/ biosci/biz042

Furuta, N., \& Shimatani, Y. (2018). Integrating ecological perspectives into engineering practicesPerspectives and lessons from Japan. International Journal of Disaster Risk Reduction, 32, 87-94. https:// doi.org/10.1016/j.ijdrr.2017.12.003

Global Environment Facility. (2020). Green infrastructure for a climate resilient society: Nature-based solutions for erosion control in Vietnam (Good Practice Briefs 2020/2). https://www.thegef.org/publications/ good-practice-brief-green-infrastructure-climateresilient-society-vietnam

Global Environment Facility. (2021a). Global Environment Facility-About us. https://www.thegef.org/ about-us

Global Environment Facility. (2021b). Global Environment Facility-Conventions. https://www.thegef. org/partners/conventions

Griscom, B. W., Adams, J., Ellis, P. W., Houghton, R. A., Lomax, G., Miteva, D. A., Schlesinger, W. H., Shoch, D., Siikamäki, J. V., Smith, P., Woodbury, P., Zganjar, C., Blackman, A., Campari, J., Conant, R. T., Delgado, C., Elias, P., Gopalakrishna, T., Hamsik, M. R., . . . Fargione, J. (2017). Natural climate solutions. PNAS, 114(44), 11645-11650. https://doi.org/ 10.1073/pnas.1710465114

Griscom, B. W., Busch, J., Cook-Patton, S. C., Ellis, P. W., Funk, J., Leavitt, S. M., Lomax, G., Turner, W. R., Chapman, M., Engelmann, J., Gurwick, N. P., Landis, E., Lawrence, D., Malhi, Y., Murray, L. S., Navarrete, D., Roe, S., Scull, S., Smith, P., ... Worthington, T. (2020). National mitigation potential from natural climate solutions in the tropics. Philosophical Transactions of the Royal Society B, 375(1794), Article 20190126. https://doi.org/10.1098/rstb.2019.0126

Hanson, H. I., Wickenberg, B., \& Olsson, J. A. (2020). Working on the boundaries-How do science use and interpret the nature-based solution concept? Land Use Policy, 90, Article 104302. https://doi.org/ 10.1016/j.landusepol.2019.104302

Hu, T., Chang, J., \& Syrbe, R.-U. (2020). Green infrastructure planning in Germany and China: A comparative approach to green space policy and planning structure. Research in Urbanism Series, 6, 99-125. https:// doi.org/10.7480/rius.6.96

Japan International Cooperation Agency. (2021). JICA's Eco-DRR cooperation in developing countries. https://www.jica.go.jp/english/our_work/thematic_ issues/disaster/c8h0vm0000bvqtv9-att/EcosystembasedDisasterRiskReduction.pdf

Jeong, D., Kim, M., Song, K., \& Lee, J. (2021). Planning a green infrastructure network to integrate potential evacuation routes and the urban green space in a coastal city: The case study of Haeundae District, Busan, South Korea. Science of the Total Environment, 761, Article 143179. https://doi.org/10.1016/ 
j.scitotenv.2020.143179

Kameyama, Y., \& Ono, K. (2021). The development of climate security discourse in Japan. Sustainability Science, 16, 271-281. https://doi.org/10.1007/s11625020-00863-1

Kang, S., \& Kim, J.-O. (2015). Morphological analysis of green infrastructure in the Seoul metropolitan area, South Korea. Landscape and Ecological Engineering, 11, 259-268. https://doi.org/10.1007/s11355-0140268-5

Kato, S., \& Huang, W. (2021). Land use management recommendations for reducing the risk of downstream flooding based on a land use change analysis and the concept of ecosystem-based disaster risk reduction. Journal of Environmental Management, 287, Article 112341. https://doi.org/10.1016/ j.jenvman.2021.112341

Kim, D. [Do-hun]., Kim, D., Lee, D.-H., Park, S., \& Kim, S. (2019). Centralization of the global REDD+ financial network and implications under the new climate regime. Forests, 10(9), Article 753. https://doi.org/ 10.3390/f10090753

Kim, D. [Dong-hwan]., Kim, D., Kim, H. S., Kim, S., \& Lee, D.-H. (2020). Determinants of bilateral REDD+ cooperation recipients in Kyoto Protocol regime and their implications in Paris Agreement regime. Forests, 11(7), Article 751. https://doi.org/10.3390/ f11070751

Korhonen-Kurki, K., Brockhaus, M., Sehring, J., Di Gregorio, M., Assembe-Mvondo, S., Babon, A., Bekele, M., Benn, V., Gebara, M. F., Kambire, H. W., Kengoum, F., Maharani, C., Menton, M., Moeliono, M., Ochieng, R., Paudel, N. S., Pham, T. T., Dkamela, G. P., \& Sitoe, A. (2019). What drives policy change for REDD+? A qualitative comparative analysis of the interplay between institutional and policy arena factors. Climate Policy, 19(3), 315-328. https://doi.org/10.1080/14693062. 2018.1507897

Laurans, Y., Ruat, R., \& Barthélemy, P. (2016). Counting on nature: How governments plan to rely on ecosystems for their climate strategies. An analysis based on intended nationally determined contributions and the Paris Agreement (IDDRI Issue Brief No. 5). IDDRI. https://www.iddri.org/sites/default/files/import/ publications/ib0516_yl-et-al_sfn_indc_en.pdf

Lechner, A. M., Gomes, R. L., Rodrigues, L., Ashfold, M. J., Selvam, S. B., Wong, E. P., Raymond, C. M., Zieritz, A., Sing, K. W., Moug, P., Billa, L., Sagala, S., Cheshmehzangi, A., Lourdes, K., Azhar, B., Sanusi, R., Ives, C. D., Tang, Y.-T., Tan, D. T., . . . Gibbins, C. (2020). Challenges and considerations of applying naturebased solutions in low- and middle-income countries in Southeast and East Asia. Blue-Green Systems, 2(1), 331-351. https://doi.org/10.2166/bgs.2020.014

Lee, J., Lim, C.-H., Kim, G. S., Markandya, A., Chowdhury, S., Kim, S. J., Lee, W.-K., \& Son, Y. (2018). Economic viability of the national-scale forestation program: The case of success in the Republic of Korea. Ecosys- tem Services, 29, 40-46. https://doi.org/10.1016/ j.ecoser.2017.11.001

Mabon, L. (2019). Enhancing post-disaster resilience by 'building back greener': Evaluating the contribution of nature-based solutions to recovery planning in Futaba County, Fukushima Prefecture, Japan. Landscape and Urban Planning, 187, 105-118. https:// doi.org/10.1016/j.landurbplan.2019.03.013

McDonald, M. (2013). Discourses of climate security. Political Geography, 33, 42-51. https://doi.org/ 10.1016/j.polgeo.2013.01.002

Mendes, R., Fidélis, T., Roebeling, P., \& Teles, F. (2020). The institutionalization of nature-based solutionsA discourse analysis of emergent literature. Resources, 9(1), Article 6. https://doi.org/10.3390/ resources 9010006

Ministry of Land, Infrastructure, Transport and Tourism. (2019). White paper on land, infrastructure, transport and tourism in Japan, 2019. https://www.mlit. go.jp/common/001325161.pdf

Ministry of the Environment. (2016). Ecosystem-based disaster risk reduction in Japan: A handbook for practitioners. https://www.env.go.jp/nature/biodic/ecodrr/pamph04.pdf

Ministry of the Environment. (2020). Looking back the year of the Japanese Presidency of the G20 in 2019 (Japan Environment Quarterly Vol. 23). http://www. env.go.jp/en/focus/jeq/issue/vol23/vol23m.pdf

Morello, E., Mahmoud, I., Gulyurtlu, S., Boelman, V., \& Davis, H. (2018). CLEVER Cities guidance on co-creating nature-based solutions: Part IDefining the co-creation framework and stakeholder engagement. CLEVER Cities. https://clevercities.eu/ fileadmin/user_upload/Resources/D1.1_Theme_5_ Co-creation_framework_FPM_12.2018.pdf

Morita, K., \& Matsumoto, K. (2015). Enhancing biodiversity co-benefits of adaptation to climate change. In W. Leal Filho (Ed.), Handbook of climate change adaptation (pp. 953-972). Springer. https://doi.org/ 10.1007/978-3-642-38670-1_21

Morita, K., \& Matsumoto, K. (2018). Synergies among climate change and biodiversity conservation measures and policies in the forest sector: A case study of Southeast Asian countries. Forest Policy and Economics, 87, 59-69. https://doi.org/10.1016/j.forpol. 2017.10.013

Nelson, D. R., Bledsoe, B. P., Ferreira, S., \& Nibbelink, N. P. (2020). Challenges to realizing the potential of nature-based solutions. Current Opinion in Environmental Sustainability, 45, 49-55. https://doi.org/ 10.1016/j.cosust.2020.09.001

Nesshöver, C., Assmuth, T., Irvine, K. N., Rusch, G. M., Waylen, K. A., Delbaere, B., Haase, D., Jones-Walters, L., Keune, H., Kovacs, E., Krauze, K., Külvik, M., Rey, F., van Dijk, J., Vistad, O. I., Wilkinson, M. E., \& Wittmer, H. (2017). The science, policy and practice of naturebased solutions: An interdisciplinary perspective. Science of the Total Environment, 579, 1215-1227. 
https://doi.org/10.1016/j.scitotenv.2016.11.106

OECD. (2020). Green infrastructure in the decade for delivery: Assessing institutional investment. https:// doi.org/10.1787/f51f9256-en

Prabhakar, S. V. R. K., Scheyvens, H., \& Takahashi, Y. (2019). Ecosystem-based approaches in G20 countries: Current status and priority actions for scaling up. Institute for Global Environmental Strategies. https://www.iges.or.jp/en/publication_documents/ pub/discussionpaper/en/6995/EbA+in+G20_

Discussion+paper+Final.pdf

Raymond, C. M., Frantzeskaki, N., Kabisch, N., Berry, P., Breil, M., Nita, M. R., Geneletti, D., \& Calfapietra, C. (2017). A framework for assessing and implementing the co-benefits of nature-based solutions in urban areas. Environmental Science and Policy, 77, 15-24. https://doi.org/10.1016/j.envsci.2017.07.008

Rohilla, S. K., Jainer, S., \& Matto, M. (2017). Green infrastructure: A practitioner's guide. Centre for Science and Environment. http://cdn.cseindia.org/ attachments/0.91656700_1505301183_GreenInfrastructure-guide.pdf

Science for Environment Policy. (2021). The solution is in nature (Future Brief 24). Publications Office of the European Union. https://doi.org/10.2779/00625

Secretariat of the Convention on Biological Diversity. (2009). Connecting biodiversity and climate change mitigation and adaptation: Report of the second ad hoc technical expert group on biodiversity and climate change (CBD Technical Series No. 41). https:// www.cbd.int/doc/publications/cbd-ts-41-en.pdf

Secretariat of the Convention on Biological Diversity. (2019). Voluntary guidelines for the design and effective implementation of ecosystem-based approaches to climate change adaptation and disaster risk reduction and supplementary information (CBD Technical Series No. 93). https://www.cbd.int/ doc/publications/cbd-ts-93-en.pdf

Seddon, N., Chausson, A., Berry, P., Girardin, C. A. J., Smith, A., \& Turner, B. (2020). Understanding the value and limits of nature-based solutions to climate change and other global challenges. Philosphical Transactions of the Royal Society B, 375, Article 20190120. https://doi.org/10.1098/rstb.2019.0120

Seddon, N., Daniels, E., Davis, R., Chausson, A., Harris, R., Hou-Jones, X., Huq, S., Kapos, V., Mace, G. M., Rizvi, A. R., Reid, H., Roe, D., Turner, B., \& Wicander, S. (2020). Global recognition of the importance of nature-based solutions to the impacts of climate change. Global Sustainability, 3, Article e15. https:// doi.org/10.1017/sus.2020.8

Seddon, N., Sengupta, S., García-Espinosa, M., Hauler, I., Herr, D., \& Rizvi, A. R. (2019). Nature-based solutions in nationally determined contributions: Synthesis and recommendations for enhancing climate ambition and action by 2020. International Union for Conservation of Nature. https://portals.iucn.org/library/ node/ 48525
Springgay, E. (2019). Forests as nature-based solutions for water. Unasy/va, 251(70), 3-13. http://www.fao. org/3/ca6842en/CA6842EN.pdf

Stern, N. (2007). The economics of climate change: The stern review. Cambridge University Press. https://doi. org/10.1017/CBO9780511817434

Swann, S., Blandford, L., Cheng, S., Cook, J., Miller, A., \& Barr, R. (2021). Public international funding of nature-based solutions for adaptation: A landscape assessment. World Resources Institute. https:// files.wri.org/d8/s3fs-public/public-internationalfunding-nature-based-solutions-adaptation_0.pdf

The Nature Conservancy. (2021). Three things to know about nature-based solutions for agriculture. https://www.nature.org/en-us/what-we-do/ourinsights/perspectives/three-things-nature-basedsolutions-agriculture

Triyanti, A., \& Chu, E. (2018). A survey of governance approaches to ecosystem-based disaster risk reduction: Current gaps and future directions. International Journal of Disaster Risk Reduction, 32, 11-21. https://doi.org/10.1016/j.ijdrr.2017.11.005

Udas-Mankikar, S., \& Driver, B. (2021). Blue-green infrastructure: An opportunity for Indian cities (ORF Occasional Paper No. 317). Observer Research Foundation. https://www.orfonline.org/research/bluegreen-infrastructure-an-opportunity-for-indiancities

UN. (2015). Paris Agreement. https://unfccc.int/sites/ default/files/english_paris_agreement.pdf

UN. (2020). A UN framework for the immediate socioeconomic response to Covid-19. https://unsdg. un.org/sites/default/files/2020-04/UN-frameworkfor-the-immediate-socio-economic-response-toCOVID-19.pdf

UN Environment Programme. (2020). UNEP and naturebased solutions. https://www.unep.org/unep-andnature-based-solutions

UN Environment Programme. (2021). Adaptation gap report 2020. https://www.unep.org/resources/ adaptation-gap-report-2020

UN Framework Convention on Climate Change. (2020). The next SCF forum-Finance for nature-based solutions. https://unfccc.int/topics/climate-finance/ events-meetings/scf-forum/the-next-scf-forumfinance-for-nature-based-solutions

UN Framework Convention on Climate Change. (2021a). Interim NDC Registry. https://www4.unfccc.int/ sites/ndcstaging/Pages/Home.aspx

UN Framework Convention on Climate Change. (2021b). Nationally Determined Contributions (NDCs). https:// unfccc.int/process-and-meetings/the-parisagreement/nationally-determined-contributionsndcs/nationally-determined-contributions-ndcs

UN Office for Disaster Risk Reduction. (2020). Ecosystembased disaster risk reduction: Implementing naturebased solutions for resilience. https://www.undrr. org/publication/ecosystem-based-disaster-risk- 
reduction-implementing-nature-based-solutions-0

UN Office for Disaster Risk Reduction. (2021). Words into action: Nature-based solutions for disaster risk reduction. https://www.undrr.org/publication/ words-action-nature-based-solutions-disaster-riskreduction

Warren, B. (2020). G20 governance of climate change through nature-based solutions. Global Solutions Journal, 5, 135-145. https://www.global-solutionsinitiative.org/wp-content/uploads/2020/05/GSJ_ issue5_NEU.pdf

Wickramasinghe, D. (2021). Ecosystem-based disaster risk reduction. In D. Benouar (Ed.), Oxford research encyclopedia of natural hazard science. https://doi. org/10.1093/acrefore/9780199389407.013.360

World Health Organization. (2021). New WHO-IUCN expert working group on biodiversity, climate, one health and nature-based solutions. https://www. who.int/news/item/30-03-2021-who-iucn-expertworking-group-biodiversity

Xing, Y., Jones, P., \& Donnison, I. (2017). Characterisation of nature-based solutions for the built environment. Sustainability, 9(1), Article 149. https://doi.org/ 10.3390/su9010149

\section{About the Authors}

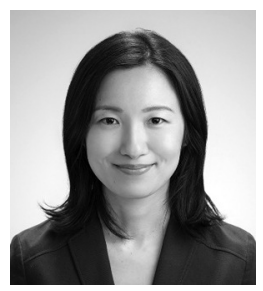

Kanako Morita is a senior researcher at the Forestry and Forest Products Research Institute, and a visiting research fellow at the United Nations University Institute for the Advanced Study of Sustainability. Her research interests focus on effective governance and financial mechanisms for sustainable development, climate change mitigation and adaptation, and biodiversity conservation. She received her $\mathrm{PhD}$ and MA from the Tokyo Institute of Technology.

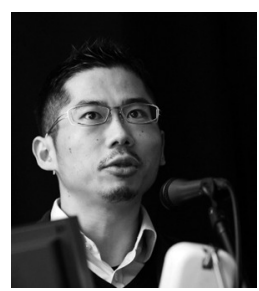

Ken'ichi Matsumoto is an associate professor of economics at the Faculty of Economics, Toyo University. His research field is environmental and energy economics and policy. His work has appeared in various peer-reviewed journals (see https://www.matsumoto-lab.net/en for his further studies). He received his PhD (Policy Studies) from Kwansei Gakuin University and his MSc from Waseda University. 